Journal of Science Education Research

Journal homepage: www.journal.uny.ac.id/jser

\title{
The Effectiveness of Two Stay Two Stray (TSTS) Cooperative Learning Model in Improving Students 'Critical Thinking Skills
}

\author{
Diaz Apriakanti ${ }^{1}$, Mobinta Kusuma ${ }^{1}$, Muriani Nurhayati ${ }^{1}$ \\ ${ }^{1}$ Natural Sciences Education, FKIP, Universitas Pancasakti Tegal \\ Corresponding Author. Email: diaz_apriakanti@upstegal.ac.id
}

Keywords:
Cooperative
Learning Model,
Two Stay Two
Stray (TSTS),
Critical Thinking
Skill

Keywords:

Cooperative

Learning Model,

Two Stay Two

Critical Thinking

Skill

\begin{abstract}
The purpose of this study was to determine (1) the differences in students' critical thinking skills in natural science subjects between those who use the Two Stay Two Stray cooperative learning model (TSTS) and those who use the Problem Based Learning (PBL) learning model (2) the effectiveness of Two Stay Two Stray (TSTS) type of cooperative learning models and Problem Based Learning (PBL) learning models in improving students' critical thinking skills. This type of research was an experiment with a Posttest-Only Control Design group method. The sampling technique used was Cluster Random Sampling to determine the experimental class and the controlled class. Data collection techniques were the test. Furthermore, the research instrument used the final test to measure students' critical thinking skills. From the results of data analysis, it was obtained the results of hypothesis testing and hypothesis testing on the effectiveness of students' critical thinking skills. The calculation results of the hypothesis test for differences in critical thinking skills of students using the Independent Samples ttest showed tcount $>$ ttable (14.710>1.674) and a significance value of 0.000 $<0.05$, while the results of the effectiveness test on students' critical thinking skills used the One Sample t-test. The test shows the value of tcount $>$ ttable (11.654> 1.708) and a significance value of $0.000<0.05$. Thus, it can be concluded that the Two Stay Two Stray (TSTS) cooperative learning model can improve students' critical thinking skills.
\end{abstract}

C2020 JSER. Yogyakarta State University

\section{INTRODUCTION}

The current dynamics of education have changed from teacher-centered learning to studentcentered learning. With the changing dynamics of this education, teachers are required to always make innovations in carrying out learning continuously, and they must also design a learning model that encourages students to be more active (Permendikbud Number 103 of 2014, 2014).

The progress and development of the 21st century require everyone to have the skills to equip themselves in facing the development of the globalization era, especially in learning. The 21 stcentury learning is carried out by directing a learning model that encourages students to discover and observe from various sources so that they are not just being told. Learning also needs to be directed to familiarize students with being able to not only formulate problems but also just solve problems. Besides, learning that is carried out must train critical thinking skills not only thinking unchangeably (Saputri et al., 2017). The application of the 2013 curriculum includes the use of innovative learning models and methods to train and integrate 4C (Creativity and Innovation, Critical Thinking and Problem Solving, Communication, Collaboration), literacy, HOTs, and Strengthening Character Education (Curriculum 2013).

The Two Stay Two Stray (TSTS) type of cooperative learning model was developed by Spencer Kagan in 1990. This learning model can be applied to all subjects and age levels (Huda, 2011). The Two Stay Two Stray structure provides an opportunity for groups to share results and information with other groups. This model viewed from the steps of the learning process can also make students confident. Furthermore, a more enthusiastic 
learning spirit will arise because students are directly involved in the learning process (Nurjanah \& Poernomo, 2016). In the Two Stay Two Stray (TSTS) cooperative learning model, each group consists of two guests and two stays which allows each group to share information with other groups. During inter-group discussions and when visiting other groups, students can build their understanding, actively cooperate to build thoughts and knowledge to better understand the problems in the subject matter. By conducting inter-group discussions, all of this will run well and be easily obtained as expected (Kusumaningtyas, 2017). Paul et al. (1993) in Fisher (2017) argues that critical thinking is a model of thinking about any matters, substances, or problems in which the thinker improves the quality of his thinking by skillfully handling the structures inherent in thinking and applying intellectual standards to them. This shows the importance of critical thinking to improve the quality of thinking so that it is more structured.

Critical thinking is thinking to compare and contrast an idea, to refine, to investigate, and to verify. It includes filtering, selecting, support ideas, making decisions, and scales. It provides a foundation for action (Surya, 2013). Critical thinking focuses on analyzing and developing the various possibilities that occur. By thinking critically, students will be able to analyze and develop their thinking.

Based on the experts' opinions on the notion of critical thinking, it can be concluded that critical thinking is the ability a person has to determine, compare, analyze, and fix existing problems in a confident and structured manner. Critical thinking aims to develop learners' perspectives and help develop judgments about how and where specific abilities can be used. Critical thinking skills are considered the foundation of other skills needed, including communication skills, collaboration skills, global awareness, technology skills, life and career skills, and learning and innovation skills. The ability to think critically is useful for stimulating other skills, such as thinking logically, being creative, solving problems, mastering the technology, and having the ability to adapt to various era changes and developments (Susilowati et al., 2018). Critical thinking requires practices. One of them is the habit of doing evaluation questions that develop critical thinking skills. In order to run the learning program well, the teacher must present learning in a clear sequence.

Two Stay Two Stray (TSTS) type of cooperative learning model can make students active and creative as well as directly involved in the learning process. Cooperative learning will encourage students to find and understand difficult concepts and be able to discuss these problems with their peers. Almost all research on cooperative learning shows that this learning can have a significant effect on the students' academic achievement. This learning is also able to increase the tolerant attitude of students towards their friends. The application of the Two Stay Two Stray (TSTS) cooperative learning model can help create learning conditions from information or knowledge transfer from teachers to a learning process that emphasizes constructing knowledge based on the understanding and experience gained both individually and in groups. The involvement of students in the Two Stay Two Stray (TSTS) cooperative learning model can help them develop critical thinking skills because students are fully involved in the learning process. In this learning process, students are required to be able to develop critical thinking skills and draw conclusions based on their understanding (Fakhriyah, 2014).

\section{METHOD}

This research used a true experimental design. The true experimental form applied was the posttest-only group design that placed the research subjects into two groups or classes. The groups were divided into the experimental class and the controlled class of the VII grade sof SMP Negeri 4 Tegal. The sampling in this study was done by using the cluster random sampling technique to get the experimental class and the controlled class. The variables in this study were the Two Stay Two Stray type of cooperative learning model $(\mathrm{X})$ and the students' critical thinking skills (Y). Data collection techniques used tests and unstructured interviews. The tests were used to measure students' critical thinking skills while interviews were done to determine the conditions that became the object of research.

The type of instrument applied in this study was multiple choice questions. Before the questions were used in the research process, an instrument is developed to determine whether it was suitable or not. This was intended to determine the validity of the questions. To analyze the data, the Independent Sample T-Test and the N-Gain effectiveness test were applied. The Independent Sample T-Test was managed to measure the difference between the Two Stay Two Stray (TSTS) type of cooperative learning model and the Problem Based Learning learning model on students' critical thinking skills. The N-Gain effectiveness test was done to see the difference in the significance of students 'critical thinking skills improvement based on students' cognitive abilities. Before testing the hypothesis, it was necessary to do the prerequisite analysis test, namely the normality test and the homogeneity test. 


\section{RESULT}

The result of this study was in the form of a posttest on environmental pollution material. The assessment was oriented towards indicators of critical thinking skills. The posttest was given to the experimental class and the controlled class. The experimental class in the teaching and learning process used the Two Stay Two Stray (TSTS) type of cooperative learning model, while the controlled class in the teaching and learning process used Problem Based Learning. The posttest results in the experimental class and controlled class were presented in table 1.

Table 1. The results of students' posttest score

\begin{tabular}{lll}
\hline Data Criteria & Experimental Class & Controlled Class \\
\hline Mean & 76,33 & 60,28 \\
Median & 77,00 & 60,00 \\
Min. Score & 67,00 & 47,00 \\
Max. Score & 93,00 & 70,00 \\
\hline
\end{tabular}

Table 1 shows that the critical thinking skills of students who were taught using the Two Stay Two Stray (TSTS) type of cooperative learning model obtained an average posttest score of 76.33 with a minimum value of 67.00 , and the maximum value of 93.00. While the critical thinking skills of students who were taught using the Problem Based Learning learning model obtained an average value of 60.28 with the minimum value of 47.00 , and the maximum value of 70.00 . These data indicated that the average posttest scores in a class using the Two Stay Two Stray (TSTS) type of cooperative learning model were higher than those in a class that used the Problem Based Learning model.

After doing the research, the students' posttest results in the experimental class and controlled class were obtained. The first hypothesis was tested using independent sample t-test analysis with the help of SPSS 17.0 software. From the calculation of students' posttest scores, it was obtained $t$ count value of 14.710 and $t$ table value of 1.674. These results indicate that 14.710 is greater than 1.674 (tcount $>$ ttable) with a significance value of 0.000 , so that $0.000<0.05$. From these calculations, it can be concluded that Ho is rejected. There was a difference in the application of the Two Stay Two Stray (TSTS) type of cooperative learning model with the Problem Based Learning learning model on the critical thinking skills of students.

Meanwhile, by testing the second hypothesis using the one sample t-test, it was obtained a tvalue of 11.654. In the table of statistical significance 0.05 (one-sided test) with degrees of freedom (df) of 25, the obtained t table was 1.708 . The calculation results show tcount was bigger than ttable (11.654> 1.708) so that $\mathrm{H} 0$ is rejected. The conclusion shows that the learning outcomes of natural science subject on environment pollution material for grade VII students who use the Two Stay Two Stray (TSTS) type of cooperative learning model are higher than those using the Problem Based Learning (PBL) learning model.

These results are in line with research conducted by Hamdi, Jammal, \& Annur (2014) that the application of the Two Stay Two Stray (TSTS) type of cooperative learning model is effective in improving students' critical thinking skills. The acquisition of normality gain (N-Gain) which is supported by statements in previous research shows that the Two Stay Two Stray (TSTS) type of cooperative learning model is effective in improving the critical thinking skills of students of SMP N 4 Tegal City compared to the reinforced Problem Based Learning model. with the results of calculating the effective value of more than one. Other studies that have been done (Ramadian, et al., 2014) prove the model

These results are in line with research conducted by Hamdi, Jammal, \& Annur (2014) that the application of the Two Stay Two Stray (TSTS) type of cooperative learning model is effective in improving students' critical thinking skills. The acquisition of normality gain ( $\mathrm{N}-\mathrm{Gain})$ which is supported by statements in previous research shows that the Two Stay Two Stray (TSTS) type of cooperative learning model is effective in improving the critical thinking skills of students of SMP N 4 Tegal City compared to the reinforced Problem Based Learning model. with the results of calculating the effective value of more than one. Another research that has been done (Ramadian, et al., 2014) proves that the Two Stay Two Stray (TSTS) cooperative learning model can improve student achievement.

\section{CONCLUSIONS}

The conclusion in this study is that there are differences in the critical thinking skills of students in science subjects between those using the Two Stay Two Stray (TSTS) cooperative learning model and those using the Problem Based 
Learning learning model. The Two Stay Two Stray (TSTS) cooperative learning model is more effective for improving students' critical thinking skills.

The researcher suggests that other researchers can add the types of students' learning activities. Other researcher should consider that there are many types of learning activities. For science teachers, the Two Stay Two Stray (TSTS) type of cooperative learning model can be used as an alternative in natural science learning on pollution material especially in improving the students' critical thinking skills.

\section{REFERENCES}

Alec Fisher. (2009). Berpikir Kritis. Sebuah Pengantar. Jakarta: Erlangga

Fakhriyah, F. (2014). Penerapan problem based learning dalam upaya mengembangkan kemampuan berpikir kritis mahasiswa. Jurnal Pendidikan IPA Indonesia, 3(1), 95101.

Fithra Ramadian, A. d. (2014). Efektivitas Model Pembelajaran Two Stay Two Stray Terhadap Peningkatan Hasil Belajardi Sma. fkip untan , 3 .

Hamdi, Jammal, \& Annur. (2014). Meningkatkan Hasil Belajar Fisika Dengan Menerapkan Model Pembelajaran Kooperatif Tipe Two Stay Two Stray. 2(3), 9.

Huda, M. (2011). Cooperative learning (Vol. 113). Yogyakarta: Pustaka Pelajar.
Kurikulum 2013. (2013). Kurikulum 2013, (Mi).

Kusumaningtyas, W. (2017). Eksperimentasi Model Pembelajaran Kooperatif Tipe Thinking Aloud Pairs Problem Solving (TAPPS) dan Two Stay Two Stray (TSTS) ditinjau dari Gaya Kognitif Siswa, 2(45), 39.

Nurjanah, S., \& Poernomo, J. B. (2016). Efektivitas Model Pembelajaran Kooperatif Tipe TTW dengan TSTS Terhadap Hasil Belajar Materi Teori Kinetik Gas. Phenomenon: Jurnal Pendidikan MIPA, 6(2), 59-70.

Permendikbud Nomor 103 Tahun 2014. (2014). Tentang Pembelajaran Pada Pendidikan Dasar Dan Pendidikan Menengah, 1-5.

Saputri, A. C., Sajidan, \& Rinanto, Y. (2017). Identifikasi Keterampilan Berpikir Kritis Siswa dalam Pembelajaran Biologi Menggunakan Window Shopping. Seminar Nasional Pendidikan Sains (SNPS), 21, 131135.

Surya, H. (2013). Strategi jitu mencapai kesuksesan belajar. Elex Media Komputindo.

Susilowati, Sajidan, \& Ramli, M. (2018). Keefektifan Perangkat Pembelajaran Berbasis Inquiry Lesson untuk Meningkatkan Keterampilan Berpkir Kritis Siswa. Jurnal Peneiltian dan Evaluasi Pendidikan, 22(1), 49-60 